\title{
PENINGKATAN KREATIFITAS DAN HASIL BELAJAR SISWA DALAM \\ MATERI SEGI BANYAK DAN LUAS GABUNGAN BANGUN DATAR MELALUI PENGgunAan ALAT PERAga BANGUN DATAR
}

\author{
Tini Eva Yulia Kartini \\ SD Negeri Harjasari 2 Kecamatan Bogor Selatan Kota Bogor \\ tinievayuliakartini@yahoo.com
}

\begin{abstract}
Abstrak : Penelitian ini bertujuan untuk (1) mengukur kreatifitas dan hasil belajar siswa dalam materi luas segi banyak dan luas gabungan bangun datar di kelas VI SD Negeri Harjasari 2 Kecamatan Bogor Selatan Kota Bogor tahun pelajaran 2018-2019 (2) mengetahui proses peningkatan kreatifitas dan hasil belajar siswa dalam materi luas segi banyak dan luas gabungan bangun datar di kelas VI SD Negeri Harjasari 2 Kecamatan Bogor Selatan Kota Bogor tahun pelajaran 2018-2019. (3) mengetahui besarnya peningkatan kreatifitas dan hasil belajar siswa dalam materi luas segi banyak dan luas gabungan bangun datar di kelas VI SD Negeri Harjasari 2 Kecamatan Bogor Selatan Kota Bogor tahun pelajaran 2018-2019.

Penelitian ini menyimpulkan bahwa penggunaan alat peraga pada materi luas segi banyak dan luas gabungan bangun datar di kelas VI di SD Negeri Harjasari 2 Kecamatan Bogor Selatan Kota Bogor sebelum menggunakan alat peraga mempunyai nilai rata-rata 53,13 Pada saat pembelajaran diubah menggunakan alat peraga bangun datar, rata-rata hasil belajar siswa meningkat menjadi 75,56 pada siklus I dan 82,64 pada siklus II. Ini berarti penggunaan alat peraga yang digunakan guru dapat meningkatkan kreatifitas dan hasil belajar siswa.
\end{abstract}

\section{Kata Kunci : $\quad$ kreatifitas, alat peraga, hasil belajar siswa, matematika}

\section{A. PENDAHULUAN}

Perbuatan mendidik diarahkan pada pencapaian tujuan pendidikan yang menyangkut kepentingan peserta didik, kepentingan masyarakat dan tuntutan lapangan pekerjaan. Proses pendidikan itu sendiri harus terarah pada peningkatan penguasaan kemampuan, pengetahuan, keterampilan, pengembangan sikap dan nilainilai dalam rangka pembentukan pengembangan diri peserta didik. Untuk mengarahkan perbuatan mendidik tersebut pemerintah mengeluarkan Undang-undang nomor 20 tahun 2003 tentang Sistem Pendidikan Nasional dan dijabarkan salah satunya Peraturan Pemerintah Nomor 19 tahun 2005 tentang Standar Nasional Pendidikan yaitu Standar Isi, Standar Proses, Standar Kompetensi Lulusan, Standar Pendidik dan Tenaga Kependidikan, Standar Saran dan Prasarana, Standar Pengelolaan, Standar Pembiayaan dan Standar Penilaian.
Berdasarkan pengalaman dan hasil pengamatan dalam pembelajaran matematika di kelas VI B SDN Harjasari 2 Kecamatan Bogor Selatan Kota Bogor, kemampuan siswa dalam menguasai materi pembelajaran belum bisa dikatakan memuaskan. Ini terbukti dari tes hasil belajar, unjuk kerja, pemantauan secara individual dan hasil evaluasi yang diperoleh siswa untuk mata pelajaran matematika hanya 20 orang dari 45 siswa atau $44,44 \%$ yang sudah menguasai materi pembelajaran. Hal tersebut menunjukkan bahwa tingkat kemampuan siswa masih rendah, salah satu penyebabnya adalah penggunaan alat peraga yang masih rendah.

Tujuan dan hasil pembelajaran terkadang tidak mencapai hasil memuaskan, ini dapat dilihat dari kemampuan siswa dalam menyelesaikan masalah yang berkaitan dengan materi pembelajaran. Dengan demikian maka guru diharuskan untuk memperbaiki pembelajaran agar kompetensi materi tersebut mampu dikuasai siswa sesuai 
dengan tujuan pembelajaran. Hal tersebut penulis alami di SDN Harjasari 2 pada pelajaran Matematika.

\section{Kreatifitas}

Salah satu tafsiran tentang hakikat kreatifitas dikemukakan oleh Ausubel, sebagai berikut: Creative achievement ... reflects a rare capacity for developing insights, sensitivities, ang appreciations in a circumscribed content area of intelectual or artistic activity.

Berdasarkan rumusan itu, maka seseorang yang kreatif adalah yang memiliki kemampuan pemahaman, sensitivitas, dan apresiasi melebihi seseorang yang tergolong intelegen. Berdasarkan eksperimen Maltzman, ternyata latihan (belajar) menambah kreativitas, baik aspek keluwesan maupun aspek keaslian dan jumlah, dari jenjang yang rendah sampai pada jenjang yang tinggi. Banyak pakar yang mendiskusikan kreativitas sebagai hasil berfikir kreatif atau pemecahan masalah. Thorrance misalnya, mendefinisikan berpikir kreatif sebagai proses penyadaran adanya gap, gangguan atau unsur- unsur yang keliru, pembentukan gagasan- gagasan atau hipotesis, pengujian hipotesis tersebut, pengkomunikasian hasil- hasil, mungkin juga pengujian kembali atau perbaikan hipotesis.

\section{Faktor-faktor mempengaruhi kreatifitas}

Faktor-faktor yang dapat mempengaruhi kreativitas menurut Rogers (Munandar, 1999) adalah:

1. Faktor internal individu

Faktor internal, yaitu faktor yang berasal dari dalam individu yang dapat mempengaruhi kreativitas, diantaranya :

a. Keterbukaan terhadap pengalaman dan rangsangan dari luar atau dalam individu. Keterbukaan terhadap pengalaman adalah kemampuan menerima segala sumber informasi dari pengalaman hidupnya sendiri dengan menerima apa adanya, tanpa ada usaha defense, tanpa kekakuan terhadap pengalaman-pengalaman tersebut. Dengan demikian individu kreatif adalah individu yang mampu menerima perbedaan

b. Evaluasi internal, yaitu kemampuan individu dalam menilai produk yang dihasilkan ciptaan seseorang ditentukan oleh dirinya sendiri, bukan karena kritik dan pujian dari orang lain. Walaupun demikian individu tidak tertutup dari kemungkinan masukan dan kritikan dari orang lain.

c. Kemampuan untuk bermaian dan mengadakan eksplorasi terhadap unsurunsur, bentuk-bentuk, konsep atau membentuk kombinasi baru dari hal-hal yang sudah ada sebelumnya.

\section{Faktor eksternal (Lingkungan)}

Faktor eksternal (lingkungan) yang dapat mempengaruhi kreativitas individu adalah lingkungan kebudayaan yang mengandung keamanan dan kebebasan psikologis. Peran kondisi lingkungan mencakup lingkungan dalam arti kata luas yaitu masyarakat dan kebudayaan. Kebudayaan dapat mengembangkan kreativitas jika kebudayaan itu memberi kesempatan adil bagi pengembangan kreativitas potensial yang dimiliki anggota masyarakat. Adanya kebudayaan creativogenic, yaitu kebudayaan yang memupuk dan mengembangkan kreativitas dalam masyarakat, antara lain :

a. Tersedianya sarana kebudayaan, misal ada peralatan, bahan dan media,

b. Adanya keterbukaan terhadap rangsangan kebudayaan bagi semua lapisan masyarakat,

c. Menekankan pada becoming dan tidak hanya being, artinya tidak menekankan pada kepentingan untuk masa sekarang melainkan berorientasi pada masa mendatang,

d. Memberi kebebasan terhadap semua warga negara tanpa diskriminasi, terutama jenis kelamin,

e. Adanya kebebasan setelah pengalamn tekanan dan tindakan keras, artinya setelah kemerdekaan diperoleh dan kebebasan dapat dinikmati,

f. Keterbukaan terhadap rangsangan kebudayaan yang berbeda,

g. Adanya toleransi terhadap pandangan yang berbeda,

h. Adanya interaksi antara individu yang berhasil, dan

i. Adanya insentif dan penghargaan bagi hasil karya kreatif. Sedangkan lingkungan 
dalam arti sempit yaitu keluarga dan lembaga pendidikan. Di dalam lingkungan keluarga orang tua adalah pemegang otoritas, sehingga peranannya sangat menentukan pembentukan kreativitas anak. Lingkungan pendidikan cukup besar pengaruhnya terhadap kemampuan berpikir anak didik untuk menghasilkan produk kreativitas, yaitu berasal dari pendidik.

\section{Hakikat Belajar}

Belajar ialah mekanisme yang dengan itu menjadikannya anggota masyarakat yang cakap, yang penting dalam menentukan semua keterampilan, pengetahuan, sikap dan nilai yang diperoleh orang sehingga menghasilkan berbagai macam tingkah laku yang berlainan.

Pendapat para ahli tentang belajar menunjukkan perbedaan yang disebabkan oleh perbedaan sudut pandang dan kondisi belajar yang diamati. Kendatipun demikian mereka sependapat bahwa perubahan tingkah laku merupakan hasil belajar melalui latihan, pengalaman dan penguatan. Bertolak dari batasan tersebut, maka dapat diindentifikasikan ciri-ciri belajar, sebagai berikut :

1. Perubahan perilaku sebagai hasil belajar mencakup semua kecakapan, ketrampilan, pengetahuan, kebiasaan, keinginan, motivasi, dan sikap.

2. Terjadinya perubahan tingkah laku sebagai hasil belajar relatif permanen atau dapat tahan untuk jangka yang cukup lama.

3. Perubahan tingkah laku sebagai hasil belajar terjadi dalam suatu proses melalui latihan dan pengalaman serta diberikan penguatan, secara verbal maupun non verbal.

4. Perubahan tingkah laku sebagai hasil belajar tidak termasuk warisan genetik, seperti : kematangan atau kedewasaan, kelelahan, perubahan bentuk tubuh, adaptasi indera, kekuatan otot, cacat fisik, penyakit, obat-obatan, dan sebagainya.

Belajar berarti mengubah tingkah laku. Hal ini sejalan dengan yang dikemukakan oleh Suhardiman (1988) bahwa belajar adalah mengubah tingkah laku. Belajar akan membantu terjadinya suatu perubahan pada diri individu yang belajar. Perubahan itu tidak hanya dikaitkan dengan perubahan ilmu pengetahuan, melainkan juga berbentuk percakapan, ketrampilan, sikap, pengertian, harga diri, minat, watak dan penyesuaian diri. Belajar menyangkut segala aspek organisme dan tingkah laku pribadi seseorang, prestasi belajar pada hakekatnya merupakan hasil dari belajar sebagai rangkaian jiwa raga. Psikofisik untuk menuju perkembangan pribadi manusia seutuhnya, yang berarti menyangkut unsur cipta, rasa, dan karsa, ranah kognitif, efektif dan prestasi motorik.

\section{Hasil Belajar}

Hasil belajar pada dasarnya adalah hasil yang dicapai dalam usaha penguasaan materi dan ilmu penegetahuan yang merupakan suatu kegiatan yang menuju terbentuknya kepribadian seutuhnya. Melalui belajar dapat diperoleh hasil yang lebih baik.

Hasil belajar dapat dikatakan sempurna apabila target jangkauan mengenai pencapaian tingkat sebagaimana yang telah diasebutkan sesuai denga tujuan belajar yang diharapkan siswa. Prestasi belajar dapat diartikan sebagai hasil maksimum yang telah dicapai oleh siswa setelah mengalami proses belajar mengajar dalam mempelajari materi pelajaran tertentu. Hasil belajar tidak mutlak berupa nilai saja, akan tetapi dapat berupa perubahan atau peningkatan sikap, kebiasaan, pengetahuan, keuletan, ketabahan, penalaran,kedisiplinan, ketrampilan dan sebagaimana yang menuju pada perubahan positif. Prestasi belajar menunjukkan kemampuan siswa yang sebenarnya yang telah mengalami proses pengalihan ilmu pengetahuan dari seseorang yang dapat dikatakan dewasa atau memiliki pengetahuan kurang. Walaupun sebenarnya prestasi ini bersifat sesaat saja, tetapi sudah dapat dikatakan bahwa siswa tersebut benar-benar memilikiilmu pada materi atau bahasan tertentu. Jadi, dengan adanya prestasi belajr, orang dapat mengetahuii seberapa jauh siswa dapat menengkap , memahami, memiliki materi pelajaran tertentu. Atas dasar itu pendidik dapat menentukan strategi belajarmengajar yang lebih baik.

\section{Pembelajaran Matematika Bangun Datar}


Berlandaskan kepada prinsip pembelajaran yang dikembangkan oleh UNESCO (Tim MKPBM 2001: 255) menyebutkan bahwa pembelajaran matematika tidak sekedar learning to know, melainkan juga harus meliputi learning to do, learning to be hingga learning to live together.

Bangun datar adalah bagian dari bidang datar yang dibatasi oleh garis-garis lurus atau lengkung ( Imam Roji,1997 ).Bangun datar dapat didefinisikan sebagai bangun yang rata mempunyai dua dimensi yaitu panjang dan lebar,tetapi tidak mempunyai tinggi atau tebal (Julius Hambali,Siskandar,dan Mohamad Rohmad,1996 ).

Berdasarkan pengertian tersebut dapat ditegaskan bahwa bangun datar merupakan bangun dua dimensi yang hanya memiliki panjang dan lebar ,yang dibatasi oleh garis lurus atau lengkung.

\section{B. METODOLOGI PENELITIAN}

Metode yang digunakan dalam penelitian ini adalah Deskriptif Analitik melalui Penelitian Tindakan Kelas,yaitu studi yang dugunakan untuk mengumpulkan data,mendekripsikan,mengolah ,menganalisa ,menyimpulkan dan menafsirkan data sehingga memperoleh gambaran yang sistematis.

Penelitian tindakan kelas ini dilakukan di SD Negeri Harjasari 2 Kecamatan Bogor Selatan Kota Bogor. Subjek penelitian adalah kelas VI dengan jumlah siswa sebanyak 45 siswa. Kelas tersebut dipakai sebagai subjek penelitian karena rata-rata hasil uji kompetensi siswa yang mencapai KKM hanya $44,4 \%$ dann hasilnya masih belum memuaskan.Oleh karena itu memerlukan penanganan yang segera.

Penelitian ini dilaksanakan pada semester ganjil tahun pelajaran 2018-2019. Waktu yang diperlukan untuk pembelajaran materi luas segi banyak dan luas gabungan bangun datar adalah 8 jam pelajaran.Dalam satu minggu 6 jam pelajaran,setiap jam berlangsung tatap muka selama 35 menit.

\section{HASIL DAN PEMBAHASAN}

\section{Pra Siklus}

Pembelajaran dimulai dengan mengadakan tes awal di kelas VI untuk mengetahui kemampuan awal siswa pada materi luas segi banyakdan luas gabungan bangun datar. Nilai tes awal dijadikan acuan untuk mengetahui hasil belajar siswa kelas VI setelah menggunakan alat peraga bangun datar. Soal-soal tes awal berupa materi yang berhubungan dengan materi yang akan diajarkan yaitu menentukan luas segi banyakdan luas gabungan bangun datar. Perolehan nilai tes awal ini dijadikan acuan untuk mengetahui peningkatan hasil belajar siswa setelah menggunakan alat peraga bangun datar. Berikut disajikan data hasil belajar pra siklus.

Tabel 1 Data Hasil Belajar Siswa Pra Siklus

\begin{tabular}{|c|c|c|c|}
\hline No & Nama Siswa & Nilai & Keterangan \\
\hline 1 & Abdillah Rafi Hardian & 73 & Tuntas \\
\hline 2 & Algia Fani & 77 & Tuntas \\
\hline 3 & Almas Tsaqieb & 70 & Tuntas \\
\hline 4 & Alwa Surya Putra & 67 & Belum Tuntas \\
\hline 5 & Annisa Putri & 63 & Belum Tuntas \\
\hline 6 & Arga Maulana & 63 & Belum Tuntas \\
\hline 7 & Asep Sunandar & 73 & Tuntas \\
\hline 8 & Dewi Sekar Ayu & 70 & Tuntas \\
\hline 9 & Dhilla Aulia Rahayu & 60 & Belum Tuntas \\
\hline 10 & Elvira Rahmadanti & 67 & Belum Tuntas \\
\hline 11 & Fitri Rimayanti & 87 & Tuntas \\
\hline 12 & Indriyani & 73 & Tuntas \\
\hline 13 & Irvan & 57 & Belum Tuntas \\
\hline 14 & Ismawati & 47 & Belum Tuntas \\
\hline 15 & Kayla Aisyah Azzahra Diaz & 73 & Belum Tuntas \\
\hline 16 & Keyla & 87 & Tuntas \\
\hline 17 & Khalafah Nursecha Hablil & 73 & Tuntas \\
\hline 18 & Maulana Yusuf & 63 & Belum tuntas \\
\hline 19 & Mia Anggraeni & 70 & Belum Tuntas \\
\hline 20 & Muhamad Aldo Abdillah Rojan & 57 & Belum Tuntas \\
\hline 21 & Muhamad Farhan Ramdani & 17 & Belum Tuntas \\
\hline 22 & $\begin{array}{l}\text { Muhamad Fitrah Putra } \\
\text { Komarudin }\end{array}$ & 37 & Belum Tuntas \\
\hline 23 & Muhamad Januar & 40 & Belum Tuntas \\
\hline 24 & Muhamad Mario & 33 & Belum Tuntas \\
\hline 25 & Muhamad Rafli Setiawan & 67 & Belum Tuntas \\
\hline 26 & Muhamad Rayhan & 37 & Belum tuntas \\
\hline 27 & Muhamad Revan Alfareza & 57 & Belum Tuntas \\
\hline 28 & Muhamad Rizky & 53 & Belum Tuntas \\
\hline 29 & Muhammad Dyrgha Satria & 77 & Tuntas \\
\hline 30 & Naufal Saputra Kurnia & 53 & Belum Tuntas \\
\hline 31 & Novi Aryanti & 73 & Belum Tuntas \\
\hline 32 & Nurul Hikmah & 67 & Belum Tuntas \\
\hline 33 & Puji Kartika Sari & 71 & Tuntas \\
\hline 34 & Rachel Aurelya & 33 & Belum Tuntas \\
\hline 35 & Raden Nabila Nur Al Adny & 67 & Tuntas \\
\hline 36 & Raul Suliano Yusuf Ryanto & 53 & Belum Tuntas \\
\hline 37 & Rehan & 80 & Tuntas \\
\hline 38 & Rismanda Octavia & 53 & Belum Tuntas \\
\hline 39 & Rival Fazri & 80 & Tuntas \\
\hline 40 & Rizka Dwi Ayu Maharani & 73 & Tuntas \\
\hline 41 & Rizki Nur Muhammad & 73 & Tuntas \\
\hline 42 & Rizkia Nur Azzahra & 53 & Belum Tuntas \\
\hline 43 & Sakti Juan Pratama & 67 & Belum Tuntas \\
\hline
\end{tabular}




\begin{tabular}{|l|l|c|c|}
\hline No & Nama Siswa & Nilai & Keterangan \\
\hline 44 & Salwa Oktavianti & 33 & Belum Tuntas \\
\hline 45 & Shinta Sucianti & 87 & Tuntas \\
\hline Nilai Tertinggi & $\mathbf{8 7}$ & \\
\hline Nilai Terendah & $\mathbf{1 7}$ & \\
\hline Rata-rata & $\mathbf{5 3 , 1 3}$ & \\
\hline
\end{tabular}

Di lihat dalam bentuk grafik dari hasil pra siklus seperti berikut :

Hasil Belajar Pra Siklus

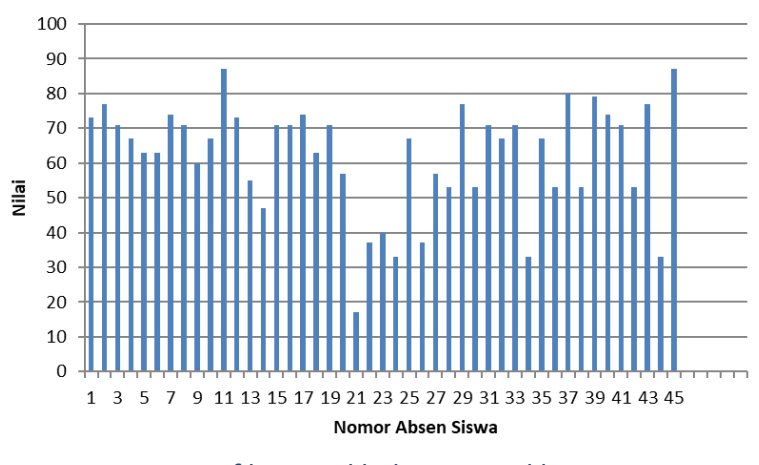

Grafik 1 Hasil belajar Pra siklus

Berdasarakan tabel dan grafik 1 terlihat bahwa siswa hanya memperoleh rata-rata 53,13 dengan nilai tertinggi 87 dan nilai terendah 17 Siswa yang hasil belajarnya di atas KKM hanya 20 siswa atau 44,4\% dari nilai KKM yang ditetapkan yaitu 70. Hal ini memberikan gambaran bahwa hasil belajar siswa pada mata pelajaran matematika masih tergolong rendah.

\section{Siklus I}

Dari hasil observasi siklus 1, didapatkan bahwa dalam melaksanakan pembelajaran matematika dengan menggunakan alat peraga bangun datar,guru telah menerapkannya sesuai dengan Rencana pelaksanaan Pembelajaran (RPP) yang telah disiapkan.Berdasarkan hasil pengamatan yang dilakukan observer,guru kurang tanggap terhadap siswa yang belum memahami materi. Masalah lain yang didapat dari pengamatan observer adalah masih ada siswa yang kurang konsentrasi dalam menerima materi pembelajaran.

Data mengenai keaktifan siswa dapat dipeoleh dengan menggunakan lembar observasi seperti pada lampiran.Keaktifan siswa tersebut dapat dilihat dalam hal bertanya dan menjawab pertanyaan dari guru maupun antusiasnya dalam mengerjakan latihan pada saat proses pembelajaran berlangsung. Data mengenai keaktifan siswa pada siklus 1 dapat dilihat pada tabel 2 berikut:

Tabel 2 Data mengenai Keaktifan Siswa Pada Siklus I

\begin{tabular}{|c|c|c|c|c|}
\hline \multirow{2}{*}{ No } & \multirow{2}{*}{ Nama Siswa } & \multicolumn{3}{|c|}{ Perhatian Siswa } \\
\hline & & Baik & Cukup & Kurang \\
\hline 1 & Abdillah Rafi Hardian & $\checkmark$ & & \\
\hline 2 & Algia Fani & $\checkmark$ & & \\
\hline 3 & Almas Tsaqieb & $\sqrt{ }$ & & \\
\hline 4 & Alwa Surya Putra & $\checkmark$ & & \\
\hline 5 & Annisa Putri & & $\checkmark$ & \\
\hline 6 & Arga Maulana & & $\checkmark$ & \\
\hline 7 & Asep Sunandar & $\checkmark$ & & \\
\hline 8 & Dewi Sekar Ayu & $\checkmark$ & & \\
\hline 9 & Dhilla Aulia Rahayu & & $\checkmark$ & \\
\hline 10 & Elvira Rahmadanti & & $\checkmark$ & \\
\hline 11 & Fitri Rimayanti & $\checkmark$ & & \\
\hline 12 & Indriyani & $\checkmark$ & & \\
\hline 13 & Irvan & & $\checkmark$ & \\
\hline 14 & Ismawati & & $\checkmark$ & \\
\hline 15 & Kayla Aisyah Azzahra Diaz & $\checkmark$ & & \\
\hline 16 & Keyla & $\checkmark$ & & \\
\hline 17 & Khalafah Nursecha Hablil & $\checkmark$ & & \\
\hline 18 & Maulana Yusuf & $\checkmark$ & & \\
\hline 19 & Mia Anggraeni & $\checkmark$ & & \\
\hline 20 & Muhamad Aldo Abdillah Rojan & & & $\checkmark$ \\
\hline 21 & Muhamad Farhan Ramdani & & & $\checkmark$ \\
\hline 22 & $\begin{array}{l}\text { Muhamad Fitrah Putra } \\
\text { Komarudin }\end{array}$ & $\checkmark$ & & \\
\hline 23 & Muhamad Januar & & & $\checkmark$ \\
\hline 24 & Muhamad Mario & & $\checkmark$ & \\
\hline 25 & Muhamad Rafli Setiawan & & $\checkmark$ & \\
\hline 26 & Muhamad Rayhan & & $\sqrt{ }$ & \\
\hline 27 & Muhamad Revan Alfareza & & & $\checkmark$ \\
\hline 28 & Muhamad Rizky & $\checkmark$ & & \\
\hline 29 & Muhammad Dyrgha Satria & $\checkmark$ & & \\
\hline 30 & Naufal Saputra Kurnia & & & $\checkmark$ \\
\hline 31 & Novi Aryanti & $\checkmark$ & & \\
\hline 32 & Nurul Hikmah & $\checkmark$ & & \\
\hline 33 & Puji Kartika Sari & $\checkmark$ & & \\
\hline 34 & Rachel Aurelya & & & $\checkmark$ \\
\hline 35 & Raden Nabila Nur Al Adny & $\checkmark$ & & \\
\hline 36 & Raul Suliano Yusuf Ryanto & & $\checkmark$ & \\
\hline 37 & Rehan & $\checkmark$ & & \\
\hline 38 & Rismanda Octavia & & $\checkmark$ & \\
\hline 39 & Rival Fazri & $\checkmark$ & & \\
\hline 40 & Rizka Dwi Ayu Maharani & $\checkmark$ & & \\
\hline 41 & Rizki Nur Muhammad & $\checkmark$ & & \\
\hline 42 & Rizkia Nur Azzahra & $\checkmark$ & & \\
\hline 43 & Sakti Juan Pratama & $\checkmark$ & & \\
\hline 44 & Salwa Oktavianti & & & $\checkmark$ \\
\hline 45 & Shinta Sucianti & $\checkmark$ & & \\
\hline \multicolumn{2}{|c|}{ Jumlah } & 27 & 11 & 7 \\
\hline \multicolumn{2}{|c|}{ Presentase } & $60 \%$ & $24,44 \%$ & $15,56 \%$ \\
\hline
\end{tabular}

Data mengenai aktifitas siswa pada siklus 1 menunjukkan bahwa $60 \%$ atau 27 siswa secara aktif mengikuti 
pembelajaran, $24,44 \%$ atau 11 siswa mengikuti pembelajaran cukup aktif dan $15,56 \%$ atau 7 siswa kurang aktif dalam mengikuti pembelajaran.

Selanjutnya di bawah ini hasil pengamatan observer tentang aktifitas guru pada siklus 1 dapat dilihat pada tabel

\begin{tabular}{|c|c|c|c|c|}
\hline \multirow{2}{*}{ No } & \multirow{2}{*}{ Aspek Yang Diamati } & \multicolumn{3}{|c|}{ Penilaian } \\
\hline & & Baik & Cukup & Kurang \\
\hline \multirow{3}{*}{1} & \multicolumn{4}{|l|}{ Pendahuluan } \\
\hline & a.Memotivasi Siswa & & $\sqrt{ }$ & \\
\hline & b.Apersepsi & $\sqrt{ }$ & & \\
\hline \multirow{7}{*}{2} & \multicolumn{4}{|l|}{ Kegiatan Inti } \\
\hline & $\begin{array}{l}\text { Bahan-bahan pembelajaran } \\
\text { yang disajikan sesuai } \\
\text { dengan yang direncanakan }\end{array}$ & $\sqrt{ }$ & & \\
\hline & $\begin{array}{l}\text { Kesesuaian pelaksanaan } \\
\text { alat peraga dengan Materi } \\
\text { pembelajaran }\end{array}$ & $\sqrt{ }$ & & \\
\hline & $\begin{array}{l}\text { Antusiasme dalam } \\
\text { menanggapi pertanyaan } \\
\text { siswa }\end{array}$ & $\sqrt{ }$ & & \\
\hline & $\begin{array}{l}\text { Membantu meningkatkan } \\
\text { proses pembelajaran siswa }\end{array}$ & $\sqrt{ }$ & & \\
\hline & $\begin{array}{l}\text { Mengarahkan siswa untuk } \\
\text { mengerjakan latihan soal }\end{array}$ & $\sqrt{ }$ & & \\
\hline & $\begin{array}{l}\text { Mengamati proses belajar } \\
\text { siswa }\end{array}$ & $\sqrt{ }$ & & \\
\hline \multirow{3}{*}{3} & \multicolumn{4}{|l|}{ Penutup } \\
\hline & Penilaian & $\sqrt{ }$ & & \\
\hline & Refleksi & $\sqrt{ }$ & & \\
\hline 4 & Pengelolaan Waktu & & $\sqrt{ }$ & \\
\hline 5 & $\begin{array}{l}\text { Penggunaan media } \\
\text { pembelajaran }\end{array}$ & $\sqrt{ }$ & & \\
\hline \multirow{3}{*}{6} & Suasana Kelas & & & \\
\hline & Semangat guru & $\sqrt{ }$ & & \\
\hline & Semangat siswa & $\sqrt{ }$ & & \\
\hline
\end{tabular}

Untuk mengetahui besaran hasil belajar siswa,maka pada akhir siklus II dilakukan tes dengan hasil belajar dapat dilihat pada tabel berikut :

\begin{tabular}{|c|l|c|c|}
\hline No & Nama Siswa & Nilai & Keterangan \\
\hline 1 & Abdillah Rafi Hardian & & \\
\hline 2 & Algia Fani & 80 & Tuntas \\
\hline 3 & Almas Tsaqieb & 87 & Tuntas \\
\hline 4 & Alwa Surya Putra & 80 & Tuntas \\
\hline 5 & Annisa Putri & 71 & Tuntas \\
\hline 6 & Arga Maulana & 73 & Tuntas \\
\hline 7 & Asep Sunandar & 87 & Tuntas \\
\hline 8 & Dewi Sekar Ayu & 80 & Tuntas \\
\hline 9 & Dhilla Aulia Rahayu & 73 & Tuntas \\
\hline 10 & Elvira Rahmadanti & 73 & Tuntas \\
\hline 11 & Fitri Rimayanti & 93 & Tuntas \\
\hline 12 & Indriyani & 87 & Tuntas \\
\hline 13 & Irvan & 63 & Tuntas \\
\hline 14 & Ismawati & 67 & Tuntas \\
\hline 15 & Kayla Aisyah Azzahra Diaz & 77 & Tuntas \\
\hline 16 & Keyla & 87 & Tuntas \\
\hline 17 & Khalafah Nursecha Hablil & 90 & Tuntas \\
\hline 18 & Maulana Yusuf & 77 & Tuntas \\
\hline 19 & Mia Anggraeni & 87 & Tuntas \\
\hline 20 & Muhamad Aldo Abdillah Rojan & 63 & Belum Tuntas \\
\hline 21 & Muhamad Farhan Ramdani & 47 & Belum Tuntas \\
\hline 22 & Muhamad Fitrah Putra & 73 & Tuntas \\
\hline 23 & Komarudin & 57 & Belum Tuntas \\
\hline & & & \\
\hline
\end{tabular}

\begin{tabular}{|c|c|c|c|}
\hline No & Nama Siswa & Nilai & Keterangan \\
\hline 24 & Muhamad Mario & 70 & Tuntas \\
\hline 25 & Muhamad Rafli Setiawan & 73 & Tuntas \\
\hline 26 & Muhamad Rayhan & 57 & Belum tuntas \\
\hline 27 & Muhamad Revan Alfareza & 67 & Belum Tuntas \\
\hline 28 & Muhamad Rizky & 70 & Tuntas \\
\hline 29 & Muhammad Dyrgha Satria & 87 & Tuntas \\
\hline 30 & Naufal Saputra Kurnia & 63 & Belum Tuntas \\
\hline 31 & Novi Aryanti & 80 & Tuntas \\
\hline 32 & Nurul Hikmah & 73 & Tuntas \\
\hline 33 & Puji Kartika Sari & 83 & Tuntas \\
\hline 34 & Rachel Aurelya & 47 & Belum Tuntas \\
\hline 35 & Raden Nabila Nur Al Adny & 83 & Tuntas \\
\hline 36 & Raul Suliano Yusuf Ryanto & 70 & Tuntas \\
\hline 37 & Rehan & 97 & Tuntas \\
\hline 38 & Rismanda Octavia & 70 & Tuntas \\
\hline 39 & Rival Fazri & 93 & Tuntas \\
\hline 40 & Rizka Dwi Ayu Maharani & 87 & Tuntas \\
\hline 41 & Rizki Nur Muhammad & 77 & Tuntas \\
\hline 42 & Rizkia Nur Azzahra & 70 & Tuntas \\
\hline 43 & Sakti Juan Pratama & 87 & Tuntas \\
\hline 44 & Salwa Oktavianti & 47 & Belum Tuntas \\
\hline 45 & Shinta Sucianti & 90 & Tuntas \\
\hline \multicolumn{2}{|c|}{ Nilai Tertinggi } & 97 & \\
\hline \multicolumn{2}{|c|}{ Nilai Terendah } & 47 & \\
\hline \multicolumn{2}{|c|}{ Rata-rata } & 75,56 & \\
\hline \multicolumn{2}{|c|}{ Jumlah siswa yang sudah tuntas } & 35 & \\
\hline \multicolumn{2}{|c|}{ Jumlah siswa yang belum tuntas } & 10 & \\
\hline \multicolumn{2}{|c|}{ Persentase Ketuntasan } & 77,78 & \\
\hline
\end{tabular}

Jika digambarkan dalam bentuk grafik, maka data hasil belajar pada siklus I tersaji pada grafik

\section{Nilai Hasil Belajar}

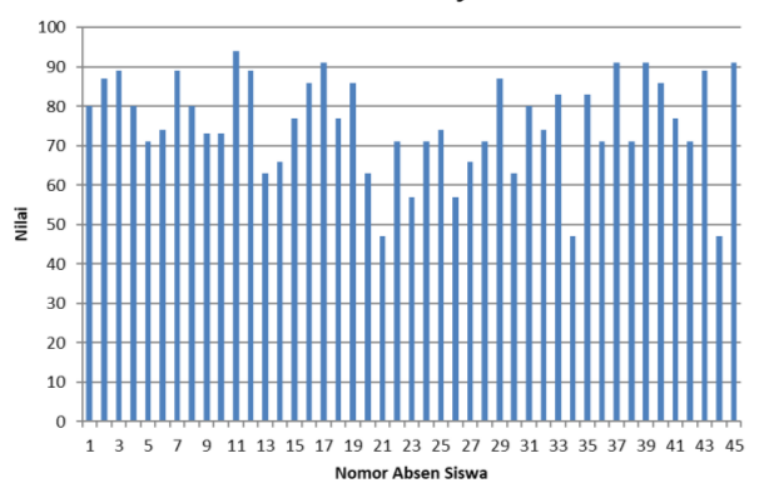

Grafik 2 Nilai hasil belajar pada Siklus I

Berdasarkan analisis data di atas, masih terdapat kekurangan-kekurangan pada siklus I. Kekurangan-kekurangan tersebut antara lain guru kurang memotivasi siswa, guru kurang peka terhadap siswa yang belum paham materi, serta kurang dalam pengelolaan waktu .Dengan adanya kekurangan-kekurangan tersebut ,maka perlu adanya perbaikan-perbaikan KBM untuk siklus II. Perbaikan tersebut yaitu dengan cara, mengadakan pendekatan baik dalam waktu proses pembelajaran berlangsung 
ataupun di luar jam proses belajar mengajar terhadap siswa yang belum paham materi pembelajaran,dan meningkatkan motivasi siswa dengan menginformasikan manfaat yang didapat dalam penerapan kehidupan sehari-hari. Selain itu guru harus lebih memperhatikan dalam pengelolaan waktu dengan pemberian materi jangan terlalu luas ,serta memperhatikan siswa terutama siswa yang belum paham materi, sehingga siswa benar-benar konsentrasi dan terlibat dalam KBM.

\section{Siklus II}

Pada siklus II ini guru telah melakukan perbaikan-perbaikan. Perbaikan dalam KBM tersebut yaitu guru lebih memotivasi siswa,sehingga siswa lebih bersemangat dalam mengikuti KBM.Dengan semangat yang tinggi ,maka pembelajaran dapat berjalan lebih baik.Selain memotivasi siswa,guru juga memberikan lebih banyak kesempatan kepada siswa untuk menanyakan hal-hal yang belum jelas.

Data mengenai keaktifan siswa dapat diperoleh dengan menggunakan lembar observasi, seperti pada lampiran. Keaktifan siswa tersebut dapat terlihat dalam hal bertanya, menjawab dan antusiasnya mengikuti pembelajaran.Data mengenai keaktifan siswa pada siklus II dapat dilihat pada tabel berikut :

\begin{tabular}{|c|l|c|c|c|}
\hline \multirow{2}{*}{ No } & \multicolumn{2}{|c|}{ Nama Siswa } & \multicolumn{3}{|c|}{ Perhatian Siswa } \\
\hline & & Baik & Cukup & Kurang \\
\hline 1 & Abdillah Rafi Hardian & $\checkmark$ & & \\
\hline 2 & Algia Fani & $\checkmark$ & & \\
\hline 3 & Almas Tsaqieb & $\checkmark$ & & \\
\hline 4 & Alwa Surya Putra & $\checkmark$ & & \\
\hline 5 & Annisa Putri & $\checkmark$ & & \\
\hline 6 & Arga Maulana & $\checkmark$ & & \\
\hline 7 & Asep Sunandar & $\checkmark$ & & \\
\hline 8 & Dewi Sekar Ayu & $\checkmark$ & & \\
\hline 9 & Dhilla Aulia Rahayu & $\checkmark$ & & \\
\hline 10 & Elvira Rahmadanti & $\checkmark$ & & \\
\hline 11 & Fitri Rimayanti & $\checkmark$ & & \\
\hline 12 & Indriyani & $\checkmark$ & & \\
\hline 13 & Irvan & $\checkmark$ & & \\
\hline 14 & Ismawati & $\checkmark$ & & \\
\hline 15 & Kayla Aisyah Azzahra Diaz & $\checkmark$ & & \\
\hline 16 & Keyla & $\checkmark$ & & \\
\hline 17 & Khalafah Nursecha Hablil & $\checkmark$ & & \\
\hline 18 & Maulana Yusuf & $\checkmark$ & & \\
\hline 19 & Mia Anggraeni & $\checkmark$ & & \\
\hline 20 & Muhamad Aldo Abdillah & $\checkmark$ & & \\
\hline & Rojan & & & \\
\hline
\end{tabular}

\begin{tabular}{|c|c|c|c|c|}
\hline \multirow{2}{*}{ No } & \multirow{2}{*}{ Nama Siswa } & \multicolumn{3}{|c|}{ Perhatian Siswa } \\
\hline & & Baik & Cukup & Kurang \\
\hline 21 & $\begin{array}{l}\text { Muhamad Farhan } \\
\text { Ramdani }\end{array}$ & & $\checkmark$ & \\
\hline 22 & $\begin{array}{l}\text { Muhamad Fitrah Putra } \\
\text { Komarudin }\end{array}$ & $\checkmark$ & & \\
\hline 23 & Muhamad Januar & & $\checkmark$ & \\
\hline 24 & Muhamad Mario & $\checkmark$ & & \\
\hline 25 & Muhamad Rafli Setiawan & $\checkmark$ & & \\
\hline 26 & Muhamad Rayhan & $\checkmark$ & & \\
\hline 27 & Muhamad Revan Alfareza & $\checkmark$ & & \\
\hline 28 & Muhamad Rizky & $\checkmark$ & & \\
\hline 29 & Muhammad Dyrgha Satria & $\checkmark$ & & \\
\hline 30 & Naufal Saputra Kurnia & $\checkmark$ & & \\
\hline 31 & Novi Aryanti & $\checkmark$ & & \\
\hline 32 & Nurul Hikmah & $\checkmark$ & & \\
\hline 33 & Puji Kartika Sari & $\checkmark$ & & \\
\hline 34 & Rachel Aurelya & & $\checkmark$ & \\
\hline 35 & Raden Nabila Nur Al Adny & $\checkmark$ & & \\
\hline 36 & Raul Suliano Yusuf Ryanto & $\checkmark$ & & \\
\hline 37 & Rehan & $\checkmark$ & & \\
\hline 38 & Rismanda Octavia & $\checkmark$ & & \\
\hline 39 & Rival Fazri & $\checkmark$ & & \\
\hline 40 & Rizka Dwi Ayu Maharani & $\checkmark$ & & \\
\hline 41 & Rizki Nur Muhammad & $\checkmark$ & & \\
\hline 42 & Rizkia Nur Azzahra & $\checkmark$ & & \\
\hline 43 & Sakti Juan Pratama & $\checkmark$ & & \\
\hline 44 & Salwa Oktavianti & & $\checkmark$ & \\
\hline 45 & Shinta Sucianti & $\checkmark$ & & \\
\hline \multicolumn{2}{|c|}{ Jumlah } & 41 & 4 & \\
\hline \multicolumn{2}{|c|}{ Presentase } & $91,11 \%$ & $8,9 \%$ & \\
\hline
\end{tabular}

Dari data keaktifan siswa pada siklus II menunjukkan bahwa $91,11 \%$ atau 41 siswa secara aktif mengikuti pembelajaran sedangkan $8,9 \%$ atau 4 siswa cukup aktif mengikuti pemebelajaran. Keaktifan siswa pada siklus II ini menunjukkan kemajuan yang sangat bagus dibandingkan dengan keaktifan siswa pada siklus I .

Di bawah ini hasil pengamatan observer tentang aktifitas guru pada siklus II dapat dilihat pada tabel berikut :

\begin{tabular}{|c|c|c|c|c|}
\hline \multirow{2}{*}{ No } & \multirow{2}{*}{ Aspek Yang Diamati } & \multicolumn{3}{|c|}{ Penilaian } \\
\hline & & Baik & Cukup & Kurang \\
\hline \multirow{3}{*}{1} & \multicolumn{4}{|l|}{ Pendahuluan } \\
\hline & a.Memotivasi Siswa & $\sqrt{ }$ & & \\
\hline & b.Apersepsi & $\sqrt{ }$ & & \\
\hline \multirow{7}{*}{2} & \multicolumn{4}{|l|}{ Kegiatan Inti } \\
\hline & $\begin{array}{l}\text { Bahan-bahan pembelajaran } \\
\text { yang disajikan sesuai } \\
\text { dengan yang direncanakan }\end{array}$ & $\sqrt{ }$ & & \\
\hline & $\begin{array}{l}\text { Kesesuaian pelaksanaan } \\
\text { alat peraga dengan Materi } \\
\text { pembelajaran }\end{array}$ & $\sqrt{ }$ & & \\
\hline & $\begin{array}{l}\text { Antusiasme dalam } \\
\text { menanggapi pertanyaan } \\
\text { siswa }\end{array}$ & $\sqrt{ }$ & & \\
\hline & $\begin{array}{l}\text { Membantu meningkatkan } \\
\text { proses pembelajaran siswa }\end{array}$ & $\sqrt{ }$ & & \\
\hline & $\begin{array}{l}\text { Mengarahkan siswa untuk } \\
\text { mengerjakan latihan soal }\end{array}$ & $\sqrt{ }$ & & \\
\hline & $\begin{array}{l}\text { Mengamati proses belajar } \\
\text { siswa }\end{array}$ & $\sqrt{ }$ & & \\
\hline 3 & \multicolumn{4}{|l|}{ Penutup } \\
\hline
\end{tabular}




\begin{tabular}{|c|l|c|c|c|}
\hline \multirow{2}{*}{ No } & \multirow{2}{*}{ Aspek Yang Diamati } & \multicolumn{3}{|c|}{ Penilaian } \\
\cline { 2 - 5 } & Penilaian & Baik & Cukup & Kurang \\
\cline { 2 - 5 } & Refleksi & $\sqrt{ }$ & & \\
\hline 4 & Pengelolaan Waktu & $\sqrt{ }$ & & \\
\hline \multirow{2}{*}{5} & $\begin{array}{l}\text { Penggunaan media } \\
\text { pembelajaran }\end{array}$ & $\sqrt{ }$ & & \\
\hline \multirow{2}{*}{6} & Suasana Kelas & & & \\
\cline { 2 - 5 } & Semangat guru & $\sqrt{ }$ & & \\
\cline { 2 - 5 } & Semangat siswa & $\sqrt{ }$ & \\
\hline
\end{tabular}

Untuk mengetahuui besaran hasil belajar siswa,maka pada akhir siklus II dilakukan tes dengan hasil belajar dapat dilihat pada tabel berikut :

Tabel 4 Data Hasil Belajar Siswa Pada Siklus II

\begin{tabular}{|c|c|c|c|}
\hline No & Nama Siswa & Nilai & Keterangan \\
\hline 1 & Abdillah Rafi Hardian & 87 & Tuntas \\
\hline 2 & Algia Fani & 93 & Tuntas \\
\hline 3 & Almas Tsaqieb & 97 & Tuntas \\
\hline 4 & Alwa Surya Putra & 87 & Tuntas \\
\hline 5 & Annisa Putri & 80 & Tuntas \\
\hline 6 & Arga Maulana & 83 & Tuntas \\
\hline 7 & Asep Sunandar & 93 & Tuntas \\
\hline 8 & Dewi Sekar Ayu & 87 & Tuntas \\
\hline 9 & Dhilla Aulia Rahayu & 77 & Tuntas \\
\hline 10 & Elvira Rahmadanti & 73 & Tuntas \\
\hline 11 & Fitri Rimayanti & 100 & Tuntas \\
\hline 12 & Indriyani & 97 & Tuntas \\
\hline 13 & Irvan & 73 & Tuntas \\
\hline 14 & Ismawati & 77 & Tuntas \\
\hline 15 & Kayla Aisyah Azzahra Diaz & 83 & Tuntas \\
\hline 16 & Keyla & 87 & Tuntas \\
\hline 17 & Khalafah Nursecha Hablil & 97 & Tuntas \\
\hline 18 & Maulana Yusuf & 87 & Tuntas \\
\hline 19 & Mia Anggraeni & 87 & Tuntas \\
\hline 20 & Muhamad Aldo Abdillah Rojan & 73 & Tuntas \\
\hline 21 & Muhamad Farhan Ramdani & 70 & Tuntas \\
\hline 22 & $\begin{array}{l}\text { Muhamad Fitrah Putra } \\
\text { Komarudin }\end{array}$ & 77 & Tuntas \\
\hline 23 & Muhamad Januar & 70 & Tuntas \\
\hline 24 & Muhamad Mario & 73 & Tuntas \\
\hline 25 & Muhamad Rafli Setiawan & 77 & Tuntas \\
\hline 26 & Muhamad Rayhan & 73 & Tuntas \\
\hline 27 & Muhamad Revan Alfareza & 73 & Tuntas \\
\hline 28 & Muhamad Rizky & 77 & Tuntas \\
\hline 29 & Muhammad Dyrgha Satria & 87 & Tuntas \\
\hline 30 & Naufal Saputra Kurnia & 73 & Tuntas \\
\hline 31 & Novi Aryanti & 87 & Tuntas \\
\hline 32 & Nurul Hikmah & 77 & Tuntas \\
\hline 33 & Puji Kartika Sari & 87 & Tuntas \\
\hline 34 & Rachel Aurelya & 77 & Tuntas \\
\hline 35 & Raden Nabila Nur Al Adny & 87 & Tuntas \\
\hline 36 & Raul Suliano Yusuf Ryanto & 77 & Tuntas \\
\hline 37 & Rehan & 97 & Tuntas \\
\hline 38 & Rismanda Octavia & 73 & Tuntas \\
\hline 39 & Rival Fazri & 90 & Tuntas \\
\hline 40 & Rizka Dwi Ayu Maharani & 93 & Tuntas \\
\hline 41 & Rizki Nur Muhammad & 77 & Tuntas \\
\hline 42 & Rizkia Nur Azzahra & 73 & Tuntas \\
\hline 43 & Sakti Juan Pratama & 93 & Tuntas \\
\hline 44 & Salwa Oktavianti & 73 & Tuntas \\
\hline 45 & Shinta Sucianti & 100 & Tuntas \\
\hline \multicolumn{2}{|c|}{ Nilai Tertinggi } & 100 & \\
\hline \multicolumn{2}{|c|}{ Nilai Terendah } & 70 & \\
\hline \multicolumn{2}{|c|}{ Rata-rata } & 82,64 & \\
\hline \multicolumn{2}{|c|}{ Jumlah siswa yang sudah tuntas } & 45 & \\
\hline
\end{tabular}

\begin{tabular}{|l|l|c|l|}
\hline No & Nama Siswa & Nilai & Keterangan \\
\hline Jumlah siswa yang belum tuntas & 0 & \\
\hline Persentase Ketuntasan & $100 \%$ & \\
\hline
\end{tabular}

Jika digambarkan dalam bentuk grafik,maka hasil belajar pada siklus IItersaji pada grafik berikut :

Nilai Hasil Belajar

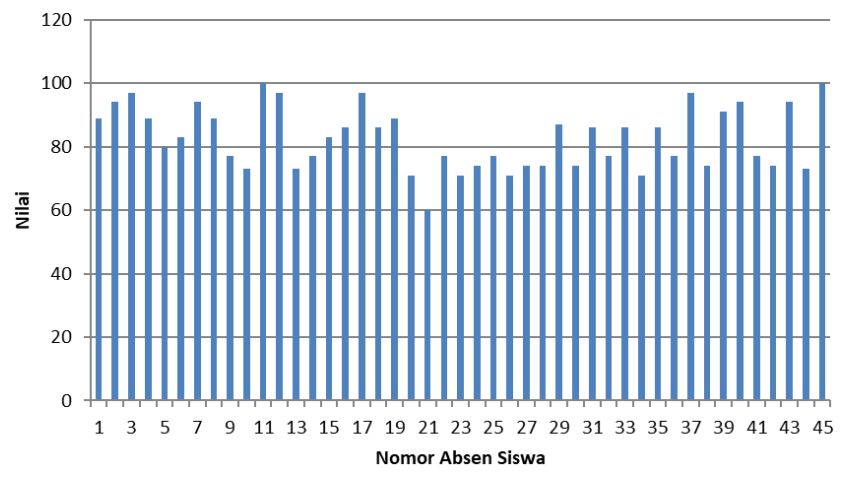

Grafik 3 Data hasil Belajar Siswa pada siklus II

Berdasarkan tabel 4 dan grafik 3 terlihat bahwa nilai rata-rata siswa 82,64 dengan nilai tertinggi 100 dan nilai terendah 60.Siswa yang hasil belajarnya di atas KKM ada 44 siswa atau $97,78 \%$ dan di bawah nilai KKM ada 1 siswa atau 2,2\% dari nilai nilai KKM yang ditetapkan yaitu 70. Hal ini memberi gambaran bahwa ada peningkatan hasil belajar siswa pada siklus I ke siklus II.

Berdasarkan hasil penelitian selama dua siklus bahwa pada pra siklus hanya 44,4\% atau 20 siswa yang nilainya di atas KKM yang ditetapkan kemudian pada siklus I meningkat menjadi $77,8 \%$ atau 35 siswa yang nilainya di atas KKM,selanjutnya pada siklus II menjadi $97,8 \%$ atau 44 siswa yang nilainya di atas KKM.

Data keaktifan siswa menunjukkan bahwa siklus 1 ada $60 \%$ atau 27 siswa yang aktif, 24,4\% atau 11 siswa yang cukup aktif dan $15,6 \%$ atau 7 siswa yang masih kurang aktif pada saat pembelajaran berlangung. Setelah guru memperbaiki hasil refleksi pada siklus I maka pada siklus II didapat $91,11 \%$ atau 41 siswa aktif pada saat pembelajarn dan $8,9 \%$ atau 4 siswa yang cukup aktif pada saat pembelajaran serta tidak ada siswa yang tidak aktif pada saat pembelajaran berlangsung.

\section{KESIMPULAN DAN SARAN}

\section{Kesimpulan}


Berdasarkan hasil penelitian yang telah dilakukan di SD Negeri Harjasari 2 Kecamatan Bogor Selatan Kota Bogor pada siswa kelas VI tahun pelajaran 2018/2019 bahawa hasil belajar siswa sesuadah menggunakan alat peraga bengun datar menunjukkan hasil yang memuaskan.Dari uraian pada bab sebelumnya, dapat diambil kesimpulan sebagai berikut :

1. Kreativitas dan hasil belajar siswa dalam materi luas segi banyak dan luas gabungan bangun datar dengan menggunakan alat peraga bangun datar, mengalami peningkatan yang sangat besar hal ini dapat dilihat hasil perolehan nilai siswa setiap siklus mengalami perubahan yang signifikan.

2. Penggunaan alat peraga bangun datar dapat menjadi variasi pembelajaran yang membuat siswa tidak bosan dan jenuh sehingga aktivitas belajar mereka meningkat. Hal ini terbukti pada siklus I ada $60 \%$ atau 27 siswa yang aktif, 24,44\% atau 11 orang siswa cukup aktif dan 15,56 $\%$ atau 7 orang siswa yang masih kurang aktif pada saat pembelajaran.Setelah guru memperbaiki hasil refleksi pada siklus I maka pada siklus II didapat $91,11 \%$ atau 41 orang siiswa yang aktif dan $8,90 \%$ atau 4 orang siswa yang cukup aktif pada saat pembelajaran serta tidak ada siswa yang tidak aktif pada saat pembelajaran.Hal ini berpengaruh terhadap hasil belajar.

3. Hasil belajar matematika pada siswa di SD Negeri Harjasari 2 Kecamatan Bogor Selatan Kota Bogor sebelum menggunakan alat peraga mempunyai nilai rata-rata 53,13 .Pada saat pembelajarn diubah menggunakan alat peraga, rata-rata hasil belajar siswa meningkat menjadi 77,78 pada siklus I dan 82,64 pada siklus II.

\section{Saran}

Setelah melaksanakan penelitian, saran yang dapat penulis ajukan adalah sebagai berikut :

1. Untuk siswa

Diharapkan siswa kelas VI SD Negeri Harjasari 2 Kecamatan Bogor Selatan Kota Bogor semakin meningkatkan aktivitas, kreativitas dan peran serta dalam KBM sehingga meningkatkan hasil belajarnya.

2. Untuk guru

Diharapkan guru menggunakan alat peraga yang disesuaikan dengan materi pembelajaran sehingga menciptakan situasi pembelajaran yang aktif, kreatif, efektif dan menyenangkan.

3. Untuk Sekolah

Diharapkan sekolah mengadakan sosialisasi dan simulasi penggunaan alat peraga dalam proses pembelajaran agar tenaga pendidik bisa memahami dan dapat menerapkannya dalam proses KBM secara benar di kelas, sehingga dapat meningkatkan kualitas pembelajaran di sekolah.

4. Untuk peneliti

Diharapkan penggunaan alat peraga dapat dikembangkan dan diterapkan pada pokok bahasan yang lain. Sehingga perlu adanya penelitian lebih lanjut sebagai pengembangan penelitian ini.

\section{DAFTAR PUSTAKA}

Muslihuddin (2011). Kiat Sukses

Melakukan Penelitian Tindakan Kelas

di Sekolah. Bandung Rizqi Press.

M. Khafid Kasri Gunanto (2008).

Matematika Aktif untuk sekolah Dasar

Kelas VI. Erlangga

Prof. Dr. Nana Syaodih Sukmadinata

(2003). Landasan Psikologi Proses

Pendidikan. PT Remaja Rosdakarya

Offset Bandung.

Mardalis ( 1995 ) Metode Penelitian, Bumi

Aksara, Jakarta

Undang-Undang Repulik Indonesia Nomor

20 (2003), Sistem Pendidikan Nasional 